\title{
MILLORA GENÈTICA DE LA TOMACA 'VALENCIANA D'EL PERELLÓ' PER A RESISTÈNCIA AL VIRUS DEL MOSAIC DE LA TOMACA (TOMATO MOSAIC VIRUS, TOMV)
}

\author{
M.R. Figàs*, A. Martín, C. Casanova, E. Soler, J. Prohens, S. Soler \\ Institut de Conservació i Millora de l'Agrodiversitat Valenciana, \\ Universitat Politècnica de València, Camino de Vera. 46022 Valencia
}

\section{*mfimo@upvnet.upv.es}

\section{Resum}

La tomaca tradicional valenciana és apreciada per les seues propietats organolèptiques que li atorguen un elevat interès comercial. En concret la tomaca 'Valenciana d'El Perelló' és cada vegada més apreciada en les superfícies comercials. Aquesta tomaca presenta diferents trets morfològics, agronòmics i de qualitat que la fan atractiva per al llaurador $\mathrm{i}$ per al consumidor. No obstant, de vegades presenta problemes d'uniformitat de producció, així com d'altres característiques importants. D'altra banda, aquesta varietat presenta una elevada susceptibilitat a malalties com la causada pel virus del mosaic de la tomaca (ToMV). Així, una forma molt interessant de potenciar aquest cultiu tan valencià, és obtenir varietats més uniformes així com resistents al ToMV. En aquest treball és du a terme tant un programa de selecció així como un programa de millora genètica de la resistència al ToMV de la tomaca 'Valenciana d'El Perelló'. Es pretén per una banda augmentar la uniformitat de producció i la presencia de trets característics d'aquesta varietat, a la vegada que s'introgressa el gen $T m 2^{2}$ de resistència al ToMV.

Paraules clau: tomaca valenciana d'el Perelló, ToMV, varietats locals, virosis, marcador molecular.

\begin{abstract}
Tomato traditional Valencian is appreciated for its organoleptic properties that confer a high commercial interest. In particular the tomato 'Valenciana d'El Perello' is increasingly appreciated in the stores. This tomato has different morphological, agronomic and quality traits that make
\end{abstract}


it attractive to the farmer and the consumer. However, sometimes presents problems of uniformity of production, as well as other important features. Moreover, this variety has a high susceptibility to diseases such as caused by the Tomato mosaic virus (ToMV). Thus, a very interesting way of promoting this Valencian crop, is to achieve more uniform and varieties resistant ToMV. In this work is carried out both a program selection as well as a program of genetic improvement of resistance to ToMV of the tomato 'Valenciana d'El Perello'. It is intended on the one hand to increase production and uniformity of the characteristics of this variety, while incorporating $T m 2^{2}$ resistance gene ToMV.

Keywords: 'valenciana d'el Perelló' tomato, ToMV, local varieties, viruses, molecular marker.

\section{1.- INTRODUCCIÓ}

La tomaca 'Valenciana d'El Perelló' és una varietat tradicional valenciana $\mathrm{amb}$ excepcionals característiques de qualitat organolèptica. Presenta fruits amb lòculs xicotets distribuïts de forma regular al voltant d'un cor de secció circular i de grans dimensions, el que li confereixen una gran fermesa i carnositat. En els darrers 5 anys aquesta varietat tradicional presenta una projecció econòmica molt important, amb una producció comercialitzada anual superior als $800.000 \mathrm{~kg}$. Per aconseguir una valorització d'aquesta varietat és necessari realitzar una caracterització morfològica $\mathrm{i}$ agronòmica que permeti la seva tipificació com a producte únic, diferenciat i de qualitat (Escrivà et al., 2010).

D'altra banda, en la tomaca 'Valenciana d'El Perelló', igual que en moltes varietats tradicionals de tomaques, es constata la inestabilitat de les produccions a causa de la incidència de malalties. Així, és important dur a terme com a mesura de suport per al cultiu d'aquest tipus de varietats la seva millora genètica, especialment per a malalties d'origen víric com la causada pel virus del mosaic de la tomaca (Tomato mosaic virus, ToMV) (Soler et al., 2010; García- Martínez et al., 2013).

En aquest context, aquest treball planteja dues activitats. La primera és la selecció de la tomaca 'Valenciana d'El Perelló' per a augmentar la seua uniformitat a nivell de característiques morfològiques i agronòmiques. La segona és la introducció de resistència al virus del mosaic de la tomaca (ToMV). L'objectiu d'aquestes tasques es valoritzar aquest cultiu, en concret de la varietat 'Valenciana d'El Perelló'. 


\section{2.- MATERIAL I MÉTODES}

\section{1.- Material vegetal}

\section{Programa de selecció de la tomaca 'Valenciana d'El Perelló'.}

Es va partir de 95 plantes de dos seleccions massals de tomaca del tipus 'Valenciana', procedents de la Cooperativa Valenciana Unió Protectora d'El Perelló (UNIPRO). El primer cicle de cultiu es van seleccionar 11 plantes de la selecció COOP-767 i 5 plantes de la selecció COOP-886. Aquestes seleccions es van efectuar en base a una caracterització morfològica i agronòmica utilitzant els següents descriptors, per tal de determinar de forma precisa les característiques típiques de la tomaca 'Valenciana d'El Perelló':

1.- Característiques de planta.

- Densitat del follatge (3, escassa; 5, intermèdia; 7, densa).

- Posició de la fulla (3, semi erecta; 5, horitzontal; 7, inclinada).

- Tipo de inflorescència (1, unípara; 2, ambos; 3, multípara).

2.- Característiques de fruit.

- Color exterior del fruit madur (coordenades L, a y b).

- Muscles en fruit no madur (0, absents; 1 , presents).

- Intensitat dels muscles (3, 1leu; 5, intermèdia; 7, forta).

- Forma predominant dels fruits (1, xatos ; 2, lleugerament xatos; 3 , redons; 4, redons-allargats; 5, cordiforme; 6, cilíndrics; 7 , piriformes; 8, el·lipsoides).

- Tamany del fruit (peso en grams).

- Homogeneïtat del tamany del fruit (3, poca; 5, intermèdia; 7, molta).

- Forma del tall transversal (1, redona; 2, angular; 3, irregular).

- Tamany del cor (en cm).

- Anàlisis Tomato Analyzer.

3.- Característiques agronòmiques.

- Fasciació del fruit (3, leugera; 5, intermèdia; 7 greu).

- Producció (en grams). 
Les plantes seleccionades es van autofecundar per a constituir les mares del primer cicle del programa de retrocreuament explicat a continuació (primavera 2015). El nombre de plantes procedents de l'autofecundació de les plantes seleccionades dels materials inicials (COOP767 i COOP-886) fou de 32. D'aquestes, es van seleccionar les plantes fenotípicament millors i es van autofecundar per a constituir les mares del segon retrocreuament (tardor 2015). D'aquestes autofecundacions es posaren al cicle següent 20 plantes per a confeccionar el tercer retrocreuament (primavera 2016) i es tornaren a seleccionar les plantes fenotípicament superiors per a constituir les mares del quart i últim retrocreuament (tardor 2016).

\section{Programa de retrocreuament.}

Per al programa de retrocreuaments es va partir de les 95 plantes de cadascuna de les 2 seleccions de tomaca 'Valenciana d'El Perelló' esmentades anteriorment, així com de 50 plantes del híbrid comercial 'Eufrates' (Syngenta). Les plantes de COOP-767 i COOP-886 seleccionades foren utilitzades com a mares del creuament inicial (C1), al ser pol·linitzades amb pol·len del parental donant de la resistència al ToMV ('Eufrates').

\section{2.- Desinfecció de llavors i realització de planters}

Amb la finalitat de reduir al màxim l'aparició de malalties transmesses per llavor es va dur a terme la desinfecció d'aquestes en cada cicle de cultiu. La desinfecció consistia en submergir les llavors en una solució de trifosfat de sodi (TSP) al 10\% durant 3 hores. Posteriorment es realitzaven 3 llavats amb aigua destil·lada de 15 minuts cadascun. El pas següent consistia en sotmetre les llavors a un tractament amb hipoclorit sòdic (lleixiu comercial) al 30\% durant 1 hora. Després d'açò es realitzava 1 llavat amb abundant aigua destil·lada. Posteriorment, les llavors es deixaven eixugar en paper de filtre. Quan les llavors estaven completament eixugades, cosa que comprovàvem mitjançant l'ús de SiliGel, es sotmetien a un procés de termoteràpia que consistia en un tractament de $80^{\circ} \mathrm{C}$ durant $24 \mathrm{~h}$ en una estufa.

Per un altre costat, una vegada les llavors havien passat pel tractament de desinfecció, es portaven a un viver comercial on es preparaven els planters. Una vegada es disposava de les plàntules amb 8-10 fulles desenvolupades, la qual cosa ocorria unes 5-6 setmanes després de la 
sembra (Febrer-Març) o unes 4 setmanes (Agost), es portaven als hivernacles de UNIPRO.

\section{3.- Condicions de cultiu}

Cada cicle de cultiu es duia a terme en hivernacles pertanyents a UNIPRO. Aquests es troben en El Perelló (Ribera Baixa). En cada cicle de cultiu les plantes es disposaren a una distancia de $0,40 \mathrm{~m}$ entre plantes $\mathrm{i}$ $1,25 \mathrm{~m}$ entre files. El nombre de plantes i files a partir del segon cicle variarien depenent de la procedència. Es a dir, si procedien de l'autofecundació de plantes del tipus 'Valenciana' fenotípicament superiors, o de la realització d'un retrocreuament.

El reg es va realitzar mitjançant sistema de degoteig o reg a manta depenent del hivernacle emprat a cada cicle. Cal destacar que el primer reg, és a dir, l'immediat després del transplantament consistia en un reg de la parcel·la a manta. El sòl tenia una textura sorra-argilosa. Les característiques d'aquest sòl fan que una fertilització addicional siga necessària. En aquest sentit, les fertilitzacions foren mitjançant l'ús de N, $\mathrm{P}_{2} \mathrm{O}_{5}$ i $\mathrm{K}_{2} \mathrm{O}$ amb una quantitat de $220 \mathrm{Kg} / \mathrm{ha}, 50 \mathrm{Kg} / \mathrm{ha}$ i $280 \mathrm{Kg} / \mathrm{ha}$ respectivament. Les males herbes s'arrencaven a ma $\mathrm{i}$ el tractament de fitosanitaris s'utilitzava quan era necessari.

\section{4.- Descripció del programa de millora realitzat}

Programa de selecció de la tomaca 'Valenciana d'El Perelló'.

Per a dur a terme aquest programa de selecció es va aplicar la "selecció individual en varietats heterogènies", en el qual a partir de dues seleccions massals (COOP-767 i COOP-886) es van realitzar seleccions en les successives generacions d'autofecundacions. Cadascun dels individus seleccionats el primer cicle de cultiu es van convertir en progenitors d'una família en la pròxima generació, a partir de la qual es va elegir de nou el millor individu. Aquest individu seleccionat en aquesta generació a la vegada es va convertir en el progenitor d'una nova família en la següent generació. D'aquesta manera el procés es va repetir durant 4 cicles de cultiu.

Programa de retrocreuament.

Per a dur a terme el programa de retrocreuament es va partir de l'híbrid 'Eufrates', el qual va actuar com a parental donant, i de les plantes seleccionades de COOP-767 i COOP-886. El primer cicle de cultiu (AbrilJuny de 2014) es van realitzar els creuaments entre aquestes plantes i 
'Eufrates', generant el creuament inicial (C1). Al segon cicle (Abril-Juny de 2015) es va dur a terme el segon retrocreuament (RC1), emprant com a mares les plantes procedents de l'autofecundació de les plantes de 'Valenciana d'El Perelló' seleccionades el primer cicle de cultiu. Com a pares es van utilitzar només aquells individus $\mathrm{C} 1$ heterozigots portador de l'al·lel de resistència $\operatorname{Tm} 2^{2}$. Per identificar aquests individus es va emprar un marcador molecular associat al gen de resistència. Cal destacar que, per a assegurar el següent cicle, els retrocreuaments no només es van fer sobre els individus de tomaca valenciana seleccionats en el programa de selecció, sinó també sobre aquells individus que més flors presentaven. A més a més, també es va fer una selecció d'aquells individus heterozigots presents en $\mathrm{RC} 1$, que sen portadors del gen de resistència, eren fenotípicament més semblants a la tomaca 'Valenciana d'El Perelló'. D'aquesta manera, es va repetir el mateix procés de selecció i creuaments, realitzant el RC2 el cicle tercer (Setembre-Desembre de 2015), el RC3 el cicle quart (Abril-Juny de 2016) i el RC4 el cicle cinqué (Setembre 2016-Gener 2017).

\section{5.- Selecció de plantes portadores del gen de resistència $T m 2^{2}$}

En aquest treball es va emprar un marcador SNP (Single Nucleotide Polymorphism) per a realitzar el genotipat d'aquelles plantes procedents del C1, RC1, RC2, RC3 i RC4. Per a dur a terme aquesta selecció assistida per marcadors ens vam basar en la publicació de Shi et al., (2011) i amb dos seqüencies disponibles en "GenBank" (FJ817600.1 i FJ817602.1) corresponents a al·lel susceptible " $t m 2^{2 "}$ " i a l'al·lel resistent " $T m 2^{2 "}$ " per a desenvolupar encebadors que ens permeteren identificar els SNPs associats al gen susceptible i al resistent. D'aquesta manera érem capaços de discernir aquelles plantes heterozigòtiques portadores del gen dominant $T m 2^{2}$ que dona resistència al ToMV d'aquelles susceptibles.

Per a poder seleccionar les plantes resistents a cadascuna de les generacions emprades ( $\mathrm{C} 1, \mathrm{RC} 1, \mathrm{RC} 2, \mathrm{RC} 3 \mathrm{i} \mathrm{RC} 4)$ es va extraure ADN genòmic de fulles joves. De cadascuna de les plantes es van prendre aproximadament $75 \mathrm{mg}$ de teixit vegetal. El protocol seguit va ser el mètode CTAB (Doyle, 1987).

Addicionalment a la selecció de les plantes resistents a cadascuna de les generacions esmentades, en cada cicle de cultiu es va dur a terme un xicotet assaig per a validar la resistència d'aquelles plantes portadores del gen de resistència $T m 2^{2}$. A partir de plantes de tomaca infectades amb la raça 0 del ToMV es va preparar un triturat de fulles. La pasta obtinguda es 
va filtrar a través d'un teixit de muselina i es va recollir el filtrat en un got de precipitats. L'extracte obtingut es va diluir en aigua destil·lada en una proporció 1:10 (pes: volum). A partir de les plantes portadores del gen $T m 2^{2}$ (identificades amb el marcador), es van obtenir esqueixos. Aquests, una volta arrelats varen ser inoculats de forma mecànic, amb l'inòcul preparat, mitjançant un aplicador de cotó. L'inòcul es va distribuir per la superfície foliar i es va comprovar que les plantes es mantenien resistents

\section{3.- RESULTATS I DISCUSIÓ}

\section{1.- Programa de selecció de la tomaca 'Valenciana d'El Perelló'}

Els resultats de la caracterització de les dos seleccions massals d'UNIPRO revelen que les característiques que defineixen de forma més precisa a la tomaca 'Valenciana d'El Perelló' són la forma de cor i apuntat del fruit en la regió pistillar. Aquests fruits presenten muscles verd intens en estat pintó i de vegades ratlles verdes que van des de la base fins al terminal de floració. Es caracteritzen també per ser molt sòlids, carnosos i amb molt poca llavor. No obstant això, per a aquestes quatre característiques es va observar variabilitat en les dues poblacions avaluades. Així, de les 95 plantes de cadascuna de les dos seleccions massals (COOP-767 i COOP886) de les quals es va partir, es van seleccionar 11 plantes de la selecció COOP-767 (22, 27, 38, 44, 50, 53, 54, 57, 63, 68 i 89) i 5 plantes de la selecció COOP-886 (41, 42, 54, 55 i 81) amb distintes combinacions de característiques. Aquestes plantes es van autofecundar per a constituir les mares del següent cicle en el programa de retrocreuaments. En els següents cicles es va repetir el procés. Actualment es disposa de la quarta generació d'autofecundació d'aquells llinatges seleccionats (taula 1, figura 1). 
Taula 1.- Característiques morfològiques dels llinatges seleccionats en el programa de selecció

\begin{tabular}{|c|c|c|c|c|c|}
\hline \multirow[b]{2}{*}{ SELECCIÓ } & \multicolumn{5}{|c|}{ CARACTERÍSTICA } \\
\hline & $\begin{array}{l}\text { Muscles } \\
\text { verds }^{\mathrm{a}}\end{array}$ & Apuntament $^{\mathrm{a}}$ & Acostellat ${ }^{\mathrm{a}}$ & $\begin{array}{l}\text { Ratlles } \\
\text { verdes }^{a}\end{array}$ & $\begin{array}{l}\text { Sequencia } \\
\text { de quallat }\end{array}$ \\
\hline COOP-767-22 & 2 & 2 & 1 & 2 & 2 \\
\hline COOP-767-27 & 3 & 3 & 1 & 2 & 2 \\
\hline COOP-767-38 & 2 & 2 & 1 & 1 & 2 \\
\hline COOP-767-44 & 3 & 2 & 1 & 2 & 2 \\
\hline COOP-767-50 & 3 & 2 & 1 & 1 & 2 \\
\hline COOP-767-53 & 3 & 2 & 1 & 3 & 2 \\
\hline COOP-767-54 & 2 & 2 & 1 & 1 & 2 \\
\hline COOP-767-57 & 3 & 3 & 1 & 1 & 3 \\
\hline COOP-767-63 & 3 & 2 & 2 & 3 & 2 \\
\hline COOP-767-68 & 2 & 3 & 2 & 2 & 2 \\
\hline COOP-767-89 & 3 & 1 & 1 & 2 & 2 \\
\hline COOP-886-41 & 1 & 2 & 1 & 1 & 1 \\
\hline COOP-886-42 & 2 & 2 & 1 & 2 & 2 \\
\hline COOP-886-54 & 3 & 3 & 1 & 1 & 2 \\
\hline COOP-886-55 & 3 & 1 & 1 & 3 & 2 \\
\hline COOP-886-81 & 3 & 2 & 1 & 1 & 2 \\
\hline
\end{tabular}

a: Intensitat del caràcter (1, baixa; 2, mitjana; 3 : alta).

b: Seqüencia de quallat (1, mitjana; 2 , bona; 3 , molt bona). 
M.R. Figàs, A. Martín, C. Casanova, E. Soler, J. Prohens, S. Soler
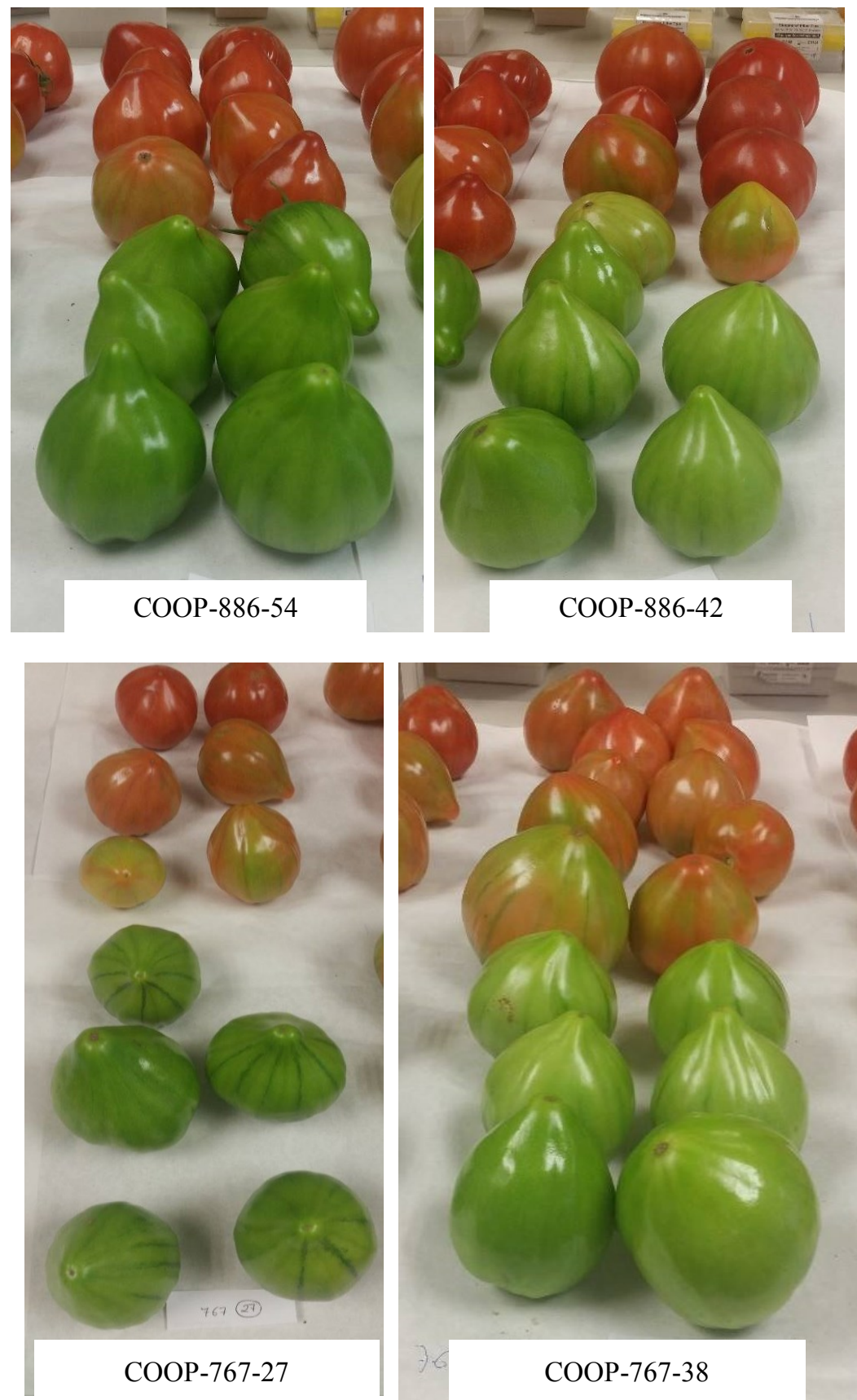

Figura 1.- Fruits verds i rojos de 4 dels 16 llinatges obtinguts de "Tomaca Valenciana d'El Perelló 


\section{2.- Programa de retrocreuament}

Les 11 plantes seleccionades de COOP-767 i les 5 de COOP-886 es van utilitzar com a mares en el C1 amb 'Eufrates' (Abril-Juny 2014). El cicle següent (Abril-Juny de 2015) es va realitzar el RC1 emprant aquelles plantes heterozigòtiques procedents del $\mathrm{C} 1 \mathrm{com}$ a parentals masculins i les plantes procedents de l'autofecundació de les 16 seleccions de 'Valenciana d'El Perelló' com a parental femení. Dels 16 llinatges originals no es va aconseguir realitzar amb èxit el RC1 amb els llinatges COOP-767-44, COOP-767-54 i COOP-767-57. Cal destacar que per al llinatge COOP-76727 , el RC1 tot i que es va poder realitzar amb èxit, no es van poder obtenir plantes d'aquest retrocreuament ja que les llavors no van germinar. D'aquesta manera, el programa de retrocreuaments va seguir amb els 12 llinatges restants. Aquest procés es va repetir realitzant així el RC2 (Setembre-Desembre de 2015). Posteriorment, (Abril-Juny de 2016) es van dur a terme els creuaments corresponents al RC3 amb els 12 llinatges citats; COOP-767-22, 38, 50, 53, 63, 68 i 89, i COOP-886-41, 42, 54, 55 i 81. Aquests RC3 presentaven una recuperació molt elevada del fenotip de 'Valenciana d'El Perelló' (figura 2). S'ha pogut també realitzar el RC4 (Setembre de 2016- Gener de 2017) amb aquests mateixos llinatges. Es va a posar en camp en el següent cicle (Abril-Juny de 2017) els RC4 obtinguts per a la seua autofecundació i poder fixar el gen $T m 2^{2}$ en homocigosis.

Cal destacar que a mesura que avançava el programa de millora i es duien a terme els creuaments, també es va fer una selecció d'aquells individus heterozigots procedents del RC1, RC2 i RC3, que sent heterozigots, eren el més semblants a la tomaca 'Valenciana d'El Perelló'. Per a dur a terme aquesta qüestió a cada planta del RC1, RC2 i RC4 se li assignava un índex de fenotip 'Valenciana d'El Perelló' $(0=$ Eufrates i $10=$ Valenciana). S'escollien com a parentals masculins dins dels RC1, RC2 i RC3 aquelles plantes amb un índex més alt (figura 2). 

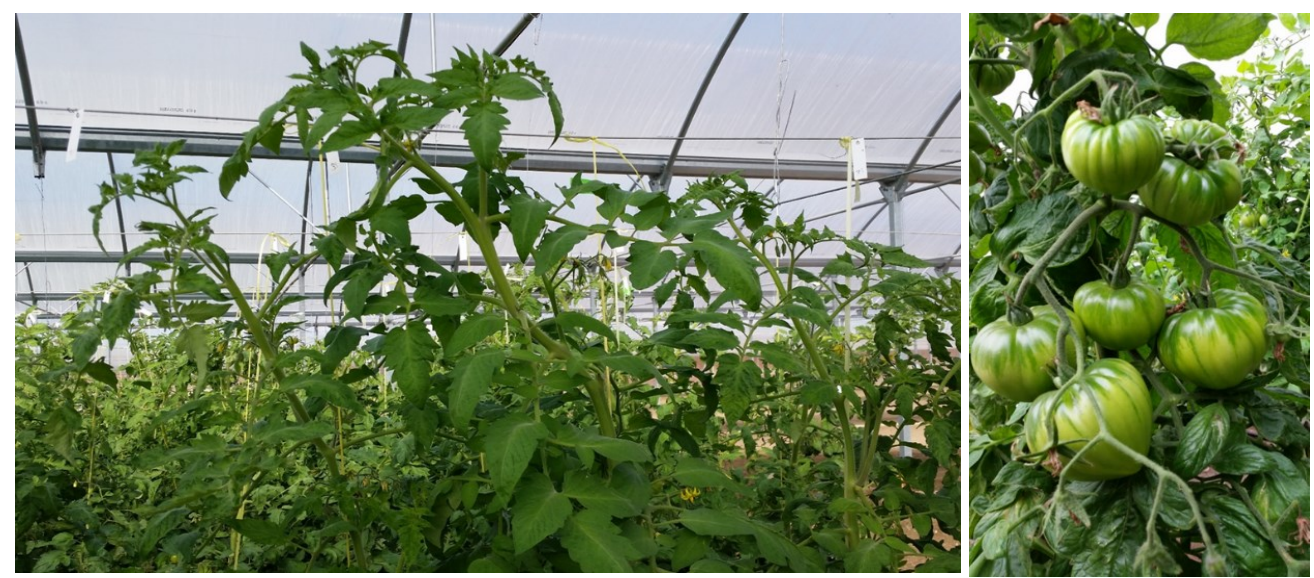

Figura 2.- Planta de RC1 (llinatge 767-27) resistent al ToMV envoltada de plantes susceptibles (esquerra) i planta de RC3 (llinatge 767-38) que ja presenta característiques típiques de la "Tomaca Valenciana d'El Perelló" (dreta).

Altre aspecte que cal tractar es la successió temporal dels cicles de cultiu realitzats. Atenent al fet que en el cultiu de la tomaca, i més a València que disposa d'hiverns suaus, es poden realitzar dos cicles de cultiu a l'any, la successió lògica de cicles en aquest programa de millora hauria d'haver sigut: 1er cicle C1 (Abril-Juny 2014), 2n cicle RC1 (SetembreDesembre de 2014), 3er cicle RC2 (Abril-Juny de 2015), 4t cicle RC3 (Setembre-Desembre de 2015) i 5è cicle RC4 (Abril-Juny de 2016). En canvi la successió real ha sigut: 1er cicle C1 (Abril-Juny 2014), 2n cicle RC1 (Abril-Juny de 2015), 3er cicle RC2 (Setembre-Desembre de 2015), 4t cicle RC3 (Abril-Juny de 2016) i 5e cicle RC4 (Setembre-Desembre de 2016). El motiu pel qual la successió de cicles va ser la segona opció és que durant la realització del cicle de Setembre-Desembre de 2014 la selección d'individus resistents es va fer a nivell de plàntula abans de trasplantar a camp, cosa que va endarrerir el trasplant. Açò va fer que es retrasara la realització de creuaments a Novembre-Desembre i es va comprometre el quallat de fruits amb llavors, obtenint-se així fruits sense llavors o amb llavors inviables. D'aquesta manera, el cicle següent (Abril-Juny de 2015) es va haver de repetir el procés per a aconseguir llavor de RC1. Cal destacar que a partir d'aquest cicle, i per evitar el retràs en els cicles de tardor i no perdre cap cicle, el genotipat es va dur a terme una vegada trasplantades les plantes.

Els resultats d'inoculació de plantes suposadament portadores del gen de resistència $T m 2^{2}$ identificades com a tals emprant el marcador 
molecular tipus SNP, confirmen la utilitat d'aquest marcador en la millora de la resistència al virus del mosaic de la tomaca. En aquest sentit, cal destacar, que en el 3er cicle de cultiu del programa de millora (SetembreDesembre de 2015) va haver un brot de ToMV a l'hivernacle on s'estava duent a terme el programa de millora (obtenció de RC2). El tret important d'açò va ser que totes les plantes que genotípicament havien estat identificades com a portadores del gen de resistència en el RC1, mostraven un vigor adequat i no mostraven símptomes de virosis (figura 2). En canvi, la resta de plantes, o siga, les homozigòtiques recessives mostraven de forma molt evident símptomes de ToMV.

\section{4.- CONCLUSIONS}

Els resultats obtinguts revelen que les característiques que defineixen de forma més precisa a la tomaca 'Valenciana d'El Perelló' són la forma de cor $\mathrm{i}$ apuntat del fruit, la presència de muscles verd intens en estat pintó i la presència de ratlles verdes al fruit. Aquest fruits es caracteritzen també per ser molt sòlids, carnosos i amb poca pulpa. No obstant això, per a aquestes quatre característiques es va observar variabilitat en les dos poblacions avaluades. Així, es van poder seleccionar individus amb diferents intensitats de apuntament, espatlles verdes, ratlles i acostellat. En l'actualitat, després de quatre cicles de selección i autofecundació es disposa de 16 seleccions o llinatges de tomaca 'Valenciana d'El Perelló' amb una alta uniformitat i bons nivells de productivitat.

Actualment, i després d'un creuament inicial i 4 cicles de retrocreuament es disposa de seleccions de RC4 per a 12 dels 16 llintages inicials de "Tomaca Valenciana d'El Perelló". La consecució d'aquest programa de millora, una vegada es facen les autofecundación per a la fixació del gen de resistencia $T m 2^{2}$, permetrà posar a disposició del llaurador un conjunt de llinatges de tomaca 'Valenciana d'El Perelló', resistents al ToMV i amb bones característiques agronòmiques.

\section{AGRAÏMENTS}

Aquest treball ha sigut financiat per la Cooperativa Valenciana Unió Protectora d'El Perelló i per el programa d'investigació e innovació Horizonte 2020 de la Unió Europea a través del contrat No. 634561 (TRADITOM;). 


\section{REFERÈNCIES BIBLIOGRÀFIQUES}

Doyle, J. 1987. A ràpid DNA isolation procedure for small quantities of fresh leaf tissue. Phytochem Bull., 19:11-15.

Escrivà, C., Baviera, A. y Buitrago, J.M. 2010. Marcas de calidad agraria en la Comunidad Valenciana. En: El derecho civil valenciano tras la reforma del estatuto de autonomía. Ed.: Ramón Fernández, F. Tirant. Valencia, España.

García- Martínez, S., Alonso, A., Rubio, F., Grau, A., Valero, M., Ruiz, J.J. 2013a. Nuevas líneas de mejora de tomate Muchamiel resistentes a virus obtenidas en el programa de mejora genética de la EPSO-UMH. VII Congreso Ibérico de Agroingeniería y Ciencias Hortícolas, Madrid.

Soler, S., Prohens, J., López, C., Aramburu, J., Galipienso, L. y Nuez, F. 2010. Viruses infecting tomato in Valencia, Spain: occurence, distribution and effect of seed origin. Journal of Phytopathology, 158: 797805 .

Shi, A., Vierling, R., Grazzini, R., Chen, P., Caton, H., y Panthee, D. 2011. Molecular markers for Tm-2 alleles of Tomato mosaic virus resistance in tomato. American Journal of Plant Sciences, 2(02), 180. 